\title{
Distribution of Phenanthrene and Methylphenanthrene in Some Nigerian Oils
}

\section{Abrakasa S and Nwankwoala $\mathrm{HO}^{*}$ \\ Department of Geology, University of Port Harcourt, Port Harcourt, Nigeria}

*Corresponding author: Nwankwoala HO, Department of Geology, University of Port Harcourt, Port Harcourt, Nigeria, Tel: +234 (0) 803672 3009; Email: nwankwoala_ho@yahoo.com

\section{Research Article \\ Volume 3 Issue 1}

Received Date: February 17, 2019

Published Date: April 05, 2019

DOI: $10.23880 /$ ppej-16000184

\section{Abstract}

The distribution of Phenanthrene and the methyl analogues in Niger Delta oils was studied. Samples were obtained from various oil fields in the Niger Delta basin. The analytical method of choice used is the GC-MS. Mass chromatograms for identification of phenanthrene and methyl phenanthrene were extracted from the data file using Enhanced MSD ChemStation 2011 software by Agilent Technologies. The objectives of this study includes identifying phenanthrene and methyl phenanthrene in the oils, delineating their abundances as parametric ratios and their application in correlation study. Most of the parametric ratios used for the study showed fairly similar range values between the oils. $\mathrm{The} P r / \mathrm{nC}_{17}$ and $\mathrm{Ph} / \mathrm{nC}_{18}$ plot inferred that the oils were generated from mixed organic matter, while the DBT/P and $\mathrm{Pr} / \mathrm{Ph}$ plot indicated that the oils were generated from organic matter in fluvial-deltaic settings with subtle variations, Umutu oil indicated shallow marine settings. Maturity of the oils as indicated by phenanthrene and methyl phenanthrene varies from early mature stage to late mature stage. Principal Component Analysis (PCA) score plot discriminated Umutu and Utorugu oils from others and the hierarchical cluster analysis (HCA) dendrogram also indicated significant difference of Umutu oil from others.

Keywords: Phenanthrene; Methylphenanthrene; Mono methyl; Crude oils; Niger Delta

Abbreviations: PCA: Principal Component Analysis; HCA: Hierarchical Cluster Analysis; GC-MS: Gas chromatography-mass spectrometry; MSD: Mass Selective Detector.

\section{Introduction}

Phenanthrenes and the methyl analogues are aromatic compounds with three benzene rings. Phenanthrenes found in fossil material had been postulated to originate from steroids and triterpenoids. Phenanthrene and the methyl analogues can be found in both natural and anthropogenic sources. Natural sources of includes oil seeps from crude oil deposits, forest fires, volcanoes and erosion of ancient sediments [1].

The partial dealkylation of the steranes and hopanoids molecules give rise to 1 - and 2- methylphenanthrene. The presence of the 3- and 9- methylphenanthrenes in ancient sediments and crude oils has been attributed to methylation of phenanthrene and rearrangement of mono-methylphenanthrene [2]. Studies have shown that 


\section{Petroleum \& Petrochemical Engineering Journal}

1-and 9-methylphenanthrenes are less stable than the 3and 2-methyl phenanthrene, hence the mechanistic postulate that are rearrangement of 1-and 9methylphenanthrene at higher temperature regimes and are used for maturation studies of compounds in crude oils [2].

Studies have shown that 1-and 9methylphenanthrenes are abundant in younger sediments and less older formations relative to 3- and 2-methyl phenanthrenes [3]. Different analogues of methylphenanthrene have been observed to show discriminative tendencies with respect to dominant organic matter type in the matrix of the source rock. Zakir Hossain HM, Sampei Y, Roser BP showed that in a study, high abundance of 1-methylphenanthrene corresponded to the abundance of higher plant organic matter [3]. 1and 9-methylphenanthrenes have also been observed to be enriched in immature sediments, and also with increasing enrichment of oleanane and Pristane.

In a study BudzinskiH, Garrigues P, Bernard G, Bellocq J, Hinrichs K [4], 1-methylphenanthrene has been related to terrestrial organic matter while 9methylphenanthrene has been associated with marine organic matter.

Actually the source of phenanthrenes and the methyl analogues can be attributed to the organic matter that constitute the source rock, the Niger Delta oils are generated from source rocks that were deposited in mega sequences constituting depobelts [5], each of the depbobelts have been deposited in slightly varying environments, the combined effect of sediment deposition, sedimentary faulting, sealevel fluctuations resulted in continuous stacking of proximal fluvio-marine sediment to distal marine sediment as cyclic events with the depobelts at different age [6]. This results in organic matter with various degree of combination of various sorts of organic inputs ranging from vascular land plants, algal and bacterial mats and planktons. The resulting petroleum generated from these organic matter will bear various compositional heterogeneity, depending on the shale and the depobelt.

The objectives of this study include:

1. To identify phenanthrenes and the mono methyl analogues in some Nigeria oils as listed in the samples subsection.

2. To delineate their abundance of the mono methyl analogues i.e. 3- and 2-methyl phenanthrenes, 1-and 9-methylphenanthrenes as parametric ratios.
3. Discriminate the Niger Delta oils, by relating phenanthrenes and the mono methyl analogues to environment of deposition.

\section{Materials and Method}

\section{Samples and Sampling}

The samples used from this study were petroleum crude oils, obtained from various well heads in various oil fields during flow test and well maintenance. The oil fields are Nembe Creek, Umutu, Afam, Enang, Usang, Rumuekpe, Abo, Clough Creek, Utorugo, Tebedaba and Azuzuama oil fields (Figure 1). Eleven samples were obtained in glass sample vials with Teflon caps. Samples were preserved in refrigerator before analysis.

\section{Pre Sample Analysis}

Samples were prepared for analysis by dissolving $10 \mathrm{mg}$ of oils in $10 \mathrm{mls}$ of hexane, to achieve the concentration of sample allowable to be injected into the GC-MS (Gas chromatography-mass spectrometry), which is $1 \mathrm{mg} / \mathrm{ml}$, the method of analysis adopted is whole oil analysis full scan. This means that the oil is not fractionated and all available compounds in the oil is scanned.

\section{GC-MS Analysis}

All the oils from different oil fields were subjected to GC-MS analysis using a HP5890 II GC with a split/spiltless injector linked to a HP 5972 MSD (Mass Selective Detector). The GC was temperature programmed for $40^{\circ} \mathrm{C}-300^{\circ} \mathrm{C}$ at $4{ }^{\circ} \mathrm{C}$ per minute and held at final temperature for $20 \mathrm{~min}$. The carrier gas was Helium (flow rate $1 \mathrm{ml} / \mathrm{min}$., pressure of $50 \mathrm{kPa}$, slit at $30 \mathrm{ml} / \mathrm{min}$ ). The ionization and identification was carried out in the HP 5972 MSD, which was equipped with electron voltage of $70 \mathrm{eV}$, filament current of $220 \mu \mathrm{A}$, source temperature of $160^{\circ} \mathrm{C}$, a multiplier voltage of $1600 \mathrm{~V}$ and interface temperature of $300^{\circ} \mathrm{C}$. The acquisition was monitored by HP Vectra 48 PC chemstation computer in both full scan mode (30ions 0.7 cps $35 \mathrm{~m}$ dwell). HP is currently known as Agilent, UK. Phenanthrene and Methylphenanthrene were detected and identified by extracting $\mathrm{m} / \mathrm{z}=178$ and $\mathrm{m} / \mathrm{z}=192$ chromatograms respectively and from literature references. Peak integration was done using the RTE integrator [7]. Data was obtained from the percentage report from the Enhanced MSD ChemStation 2011 software by Agilent Technologies. 


\section{Petroleum \& Petrochemical Engineering Journal}

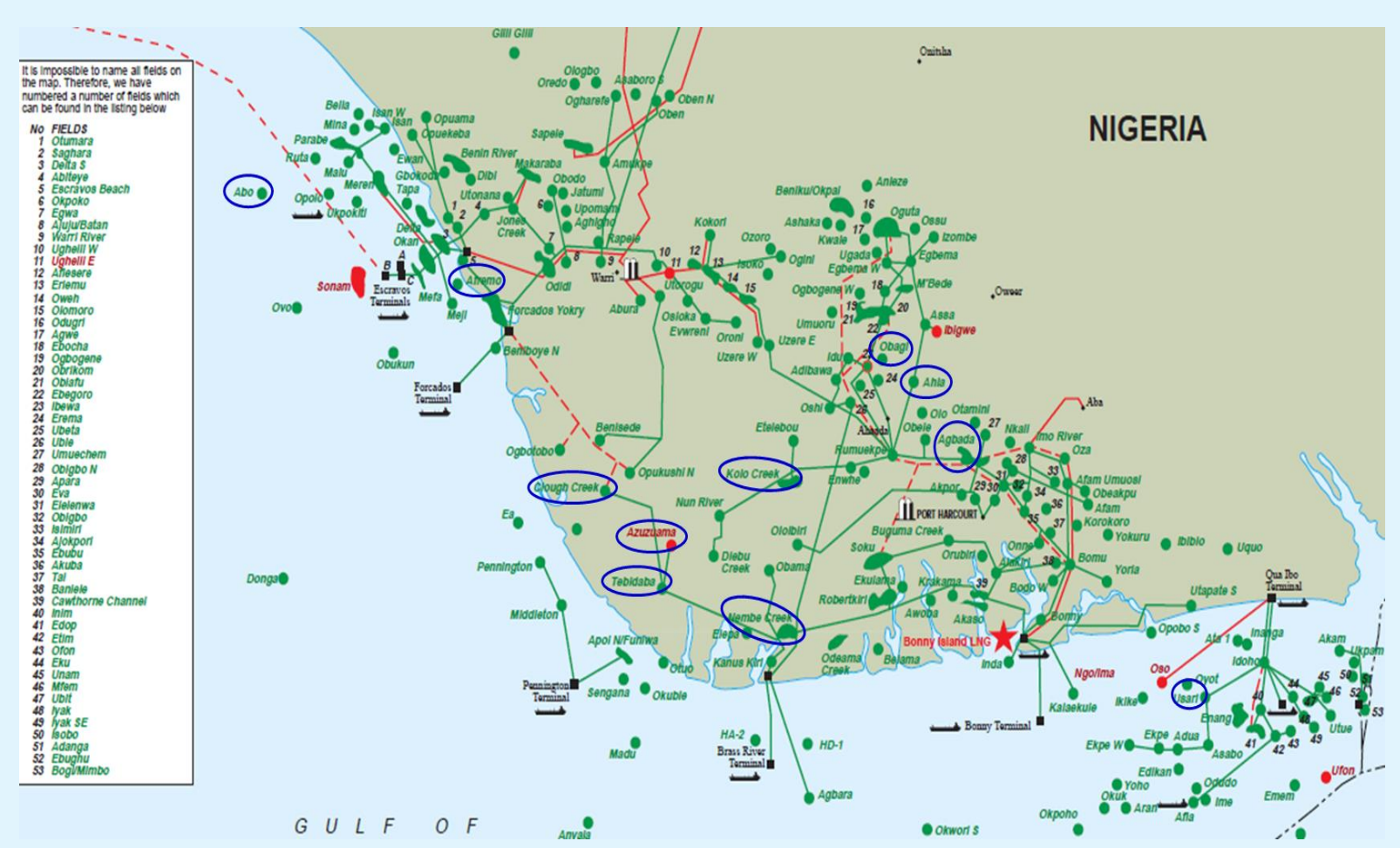

Figure 1: Map of Southern Nigeria showing some of the oil fields studied.

\section{Result and Discussion}

\section{Identification of Phenanthrene and Methylphenanthrene}

Phenanthrene peak always appear as a single peak on the $\mathrm{m} / \mathrm{z}=178$ chromatogram (Figure 1), while the methylphenanthrene peaks appears as two doublet on the $\mathrm{m} / \mathrm{z}=192$ chromatogram (Figure 2) [7,8]. Their abundances can be extracted by integrating with RTE integrator for the correct retention time, based on the retention time the peak area can be extracted from the percent report generated by the Enhanced MSD ChemStation 2011 software by Agilent Technologies. The extracted values were used to calculate the various parametric ratios used in the study.

Table 1 shows the various parametric ratios derived from the percent report from the chemstation software. It is observed that the DPT/P ratio is very high for the Umutu oil. The $\mathrm{Pr} / \mathrm{Ph}$ ratio are all higher than 1.0. The Utorugu oil show very high $\mathrm{Pr} / \mathrm{nC}_{17}$ ratio, relative to oils from other oil fields. As observed in Table 1, the phenanthrene and methylphenanthrene are variable in abundance. All methylphenanthrene based ratios did not show any significant difference but subtle variations which reflects minute or negligible differences.

\section{Oil Correlation Studies}

The ratios obtained can be used in oil correlation studies. They can be used to also discriminate oils [7]. Oil correlation studies entails the use of biomarkers in establishing genetic relationships of oil based on the premise that oils generated from a source rock bearing the same organic matter should have similar characteristics and should behave in similar manner when subject to robust analytical statistical processes [9].

\section{Depositional Environment}

Depositional environment entails the palaeoenvironment where the source rock that generated the oils were deposited. The $\mathrm{Pr} / \mathrm{nC}_{17}$ and $\mathrm{Ph} / \mathrm{nC}_{18}$ plot of had been used to preliminarily determine palaeoenvironment of deposition and potentially the organic matter type embedded in the source rock [10]. In this study, the $\mathrm{Pr} / \mathrm{nC}_{17}$ and $\mathrm{Ph} / \mathrm{nC}_{18}$ plot in Figure 3, infers that the organic matter embedded in the source rock generating the oils were deposited in a suboxic 


\section{Petroleum \& Petrochemical Engineering Journal}

environment. Suboxic environment contains about 0.2$0.0 \mathrm{~mL} \mathrm{~L}^{-1}$ of dissolved oxygen in the waters during deposition of the organic matter [11].

The plot in Figure 3 also indicate that the organic matter that generated the oils are mixed consisting of vascular plant materials via continental runoffs and bacterial mats in marine-like settings in distal environments from the continental slope. The Utorugu oil show the very high values of the $\mathrm{Pr} / \mathrm{nC}_{17}$ and $\mathrm{Ph} / \mathrm{nC}_{18}$ which may like be attributed biodegradation. The plot of DBT $/ \mathrm{P}$ and $\mathrm{Pr} / \mathrm{Ph}$ has been used to delineate environment of deposition of source rocks for generated oils [12].

In this study, the plot of DBT/P and $\mathrm{Pr} / \mathrm{Ph}$ (Figure 3) was employed to delineate the environment of deposition of the source rock that generated the oils. The plot infers that all oils are were generated by source rocks that were deposited in fluvial-deltaic environment, however, Umutu oil is discriminated from all others, which implies that the source rock for the Umutu oil is deposited in environment that is of shallow marine to near shore organic facies [12]. High DBT (Dibenzothiophene) reflects marine environment that is sulfur rich from marine volcanoes, while $\mathrm{P}$ (phenanthrene) reflects vascular plants inputs from continental runoffs. Low DPT/P ratios reflects oils that are generated from source rock that have high vascular plants materials and were deposited in fluvialdeltaic environment or low sulfur due to the scrubbing of sulfur by ferruginous sediment [13]. High $\mathrm{Pr} / \mathrm{Ph}$ ratios reflect oils generated from source rocks that were deposited in oxygen deficient environment [7].

\begin{tabular}{|c|c|c|c|c|c|c|c|c|c|}
\hline Wells & $\mathrm{Pr} / \mathrm{Ph}$ & $\mathrm{Pr} / \mathrm{nC} 17$ & $\mathrm{Ph} / \mathrm{nC18}$ & DBT/P & $(9+1) /($ Total $)$ & $(9+1) /(3+2)$ & $9 /($ Total $)$ & $1 /($ Total) & MPI \\
\hline Abo & 2.32 & 0.63 & 0.34 & 0.64 & 0.51 & 1.02 & 0.31 & 0.2 & 0.8 \\
\hline Azuzuama & 2.66 & 1.52 & 0.69 & 0.12 & 0.47 & 0.89 & 0.28 & 0.19 & 0.8 \\
\hline Clough Creek & 3.17 & 1.09 & 0.44 & 0.05 & 0.57 & 1.32 & 0.28 & 0.29 & 0.5 \\
\hline Nembe Creek & 2.31 & 0.52 & 0.32 & 0.82 & 0.44 & 0.78 & 0.29 & 0.15 & 0.9 \\
\hline Rumuekpe & 1.93 & 3.5 & 1.75 & 0.1 & 0.54 & 1.16 & 0.34 & 0.2 & 0.73 \\
\hline Tebidaba & 3.34 & 0.47 & 0.57 & 0.02 & 0.68 & 2.1 & 0.45 & 0.23 & 0.24 \\
\hline Umutu & 2.98 & 0.38 & 0.14 & 46.88 & 0.47 & 0.88 & 0.29 & 0.18 & 0.8 \\
\hline Usan & 1.74 & 1.69 & 1.4 & 0.07 & 0.6 & 1.47 & 0.33 & 0.26 & 0.61 \\
\hline Utorugu & 2.96 & 15.18 & 6.05 & 0.01 & 0.43 & 0.75 & 0.25 & 0.17 & 1.04 \\
\hline Enang & 1.01 & 2.75 & 1.37 & 0 & 0.5 & 1 & 0.29 & 0.21 & 0.92 \\
\hline Afam & 1.95 & 5.45 & 2.34 & 5.68 & $\mathrm{Na}$ & na & na & $\mathrm{Na}$ & na \\
\hline Kolo Creek & 2.78 & 0.58 & 0.25 & 9.14 & $\mathrm{Na}$ & na & na & $\mathrm{Na}$ & na \\
\hline
\end{tabular}

Table 1: Ratio of Biomarker Parameters obtained from the percentage report.

$\mathrm{Pr}=$ Pristane, $\mathrm{Ph}=$ Phytane, $\mathrm{DPT}=$ Dibenzothiophene, $\mathrm{P}=$ Phenanthrene, $1=1$-methylphenanthrene, $9=9$ methylphenanthrene, $2=2$ - methylphenanthrene, $3=3$ - methylphenanthrene, Total sum of all methylphenanthrene, MPI=Methylphenanthrene index.

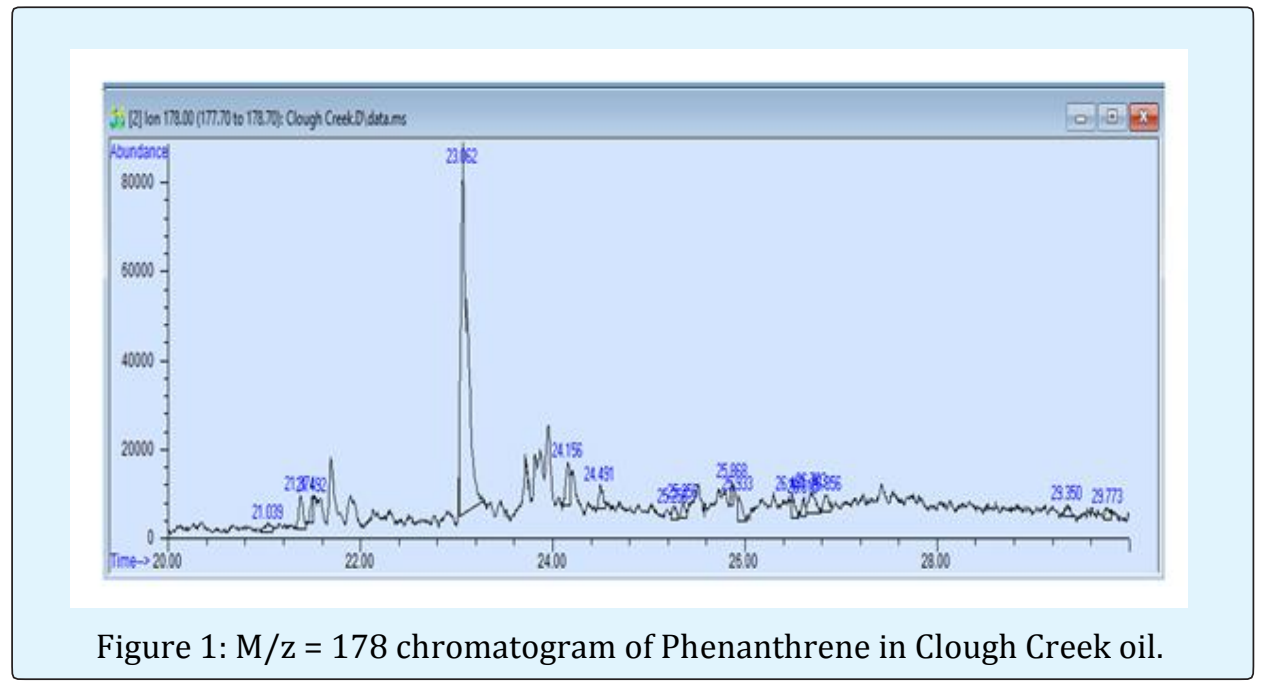




\section{Petroleum \& Petrochemical Engineering Journal}

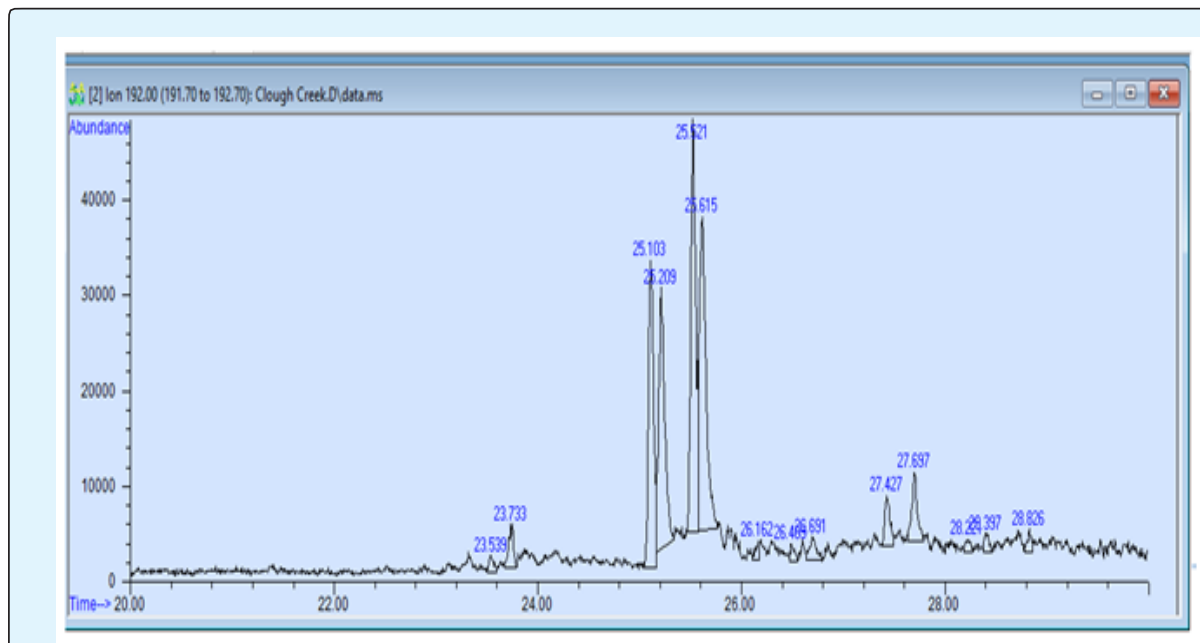

Figure 2: M/z = 192 chromatogram of methylphenanthrene in Clough Creek oil.

\section{Maturity}

The maturity of oil reflects the extent to which the source rock generating the oil has transformed into the oil window, which is the burial depth at which oil generation commences. The MPI (methylphenanthrene index) has been used as one of the aromatic biomarker ratios for expressing maturity oils [14]. The MPI is expressed as MPI-1=1.5*[3-MP+2-MP]/[P+9-MP+1-MP]. The conversion to calculated vitrinite reflectance $(\% \mathrm{Rc})$ is achieved with the expression \%Rc (MPI-1) $=0.6 * \mathrm{MPI}-$ $1+0.4$. The plot of MPI-1 and $(9+1) /($ Total MP) in Figure 4 show that the maturity of the oils studied varies with the most matured oil being Utorugu and the less matured being Tebidaba. The plot also show an excellence inverse relationship between MPI- 1 and $(9+1) /($ Total MP), by the MPI-1 values, the oils studied varies in maturity from early mature stage, where there is transition from kerogen to wet gas and soluble bitumen to late mature stage, which consist light oils and indicates transition to condensate and wet gas. The subtle variations in maturity indicates that generation did not commence at the same time and deposition of the source rock could have been at different times, this corroborates the depobelt concept, which postulates the deposition of the basins in mega sequences at particular time frame $[5,6]$.

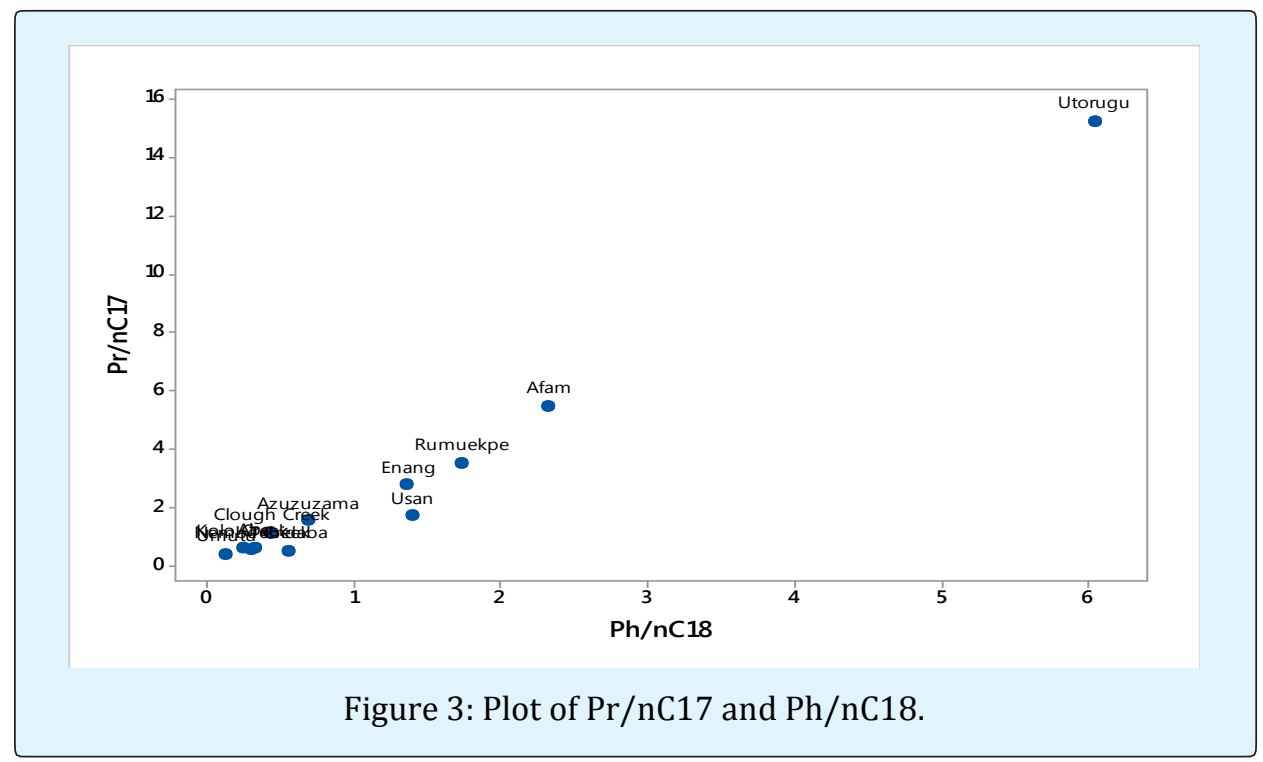




\section{Petroleum \& Petrochemical Engineering Journal}

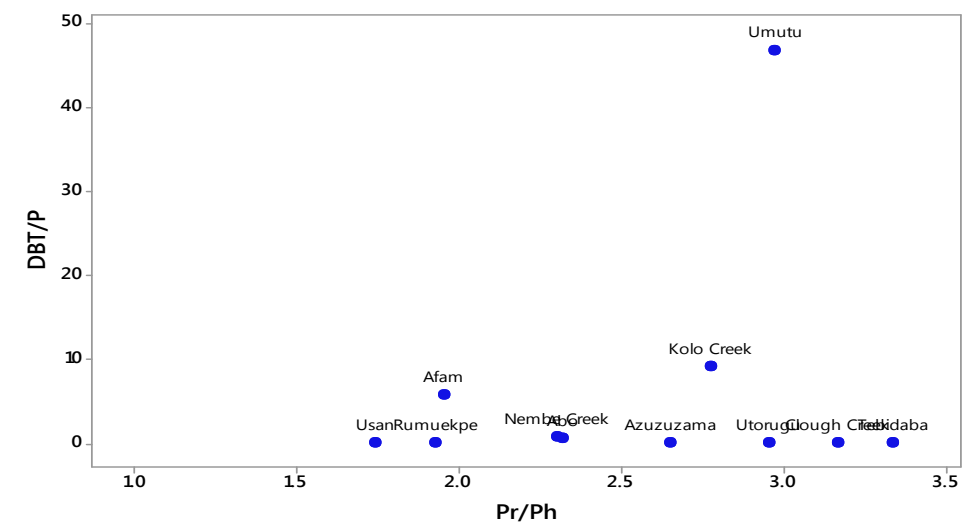

Figure 4: Plot of DBT/P and Pr/Ph.

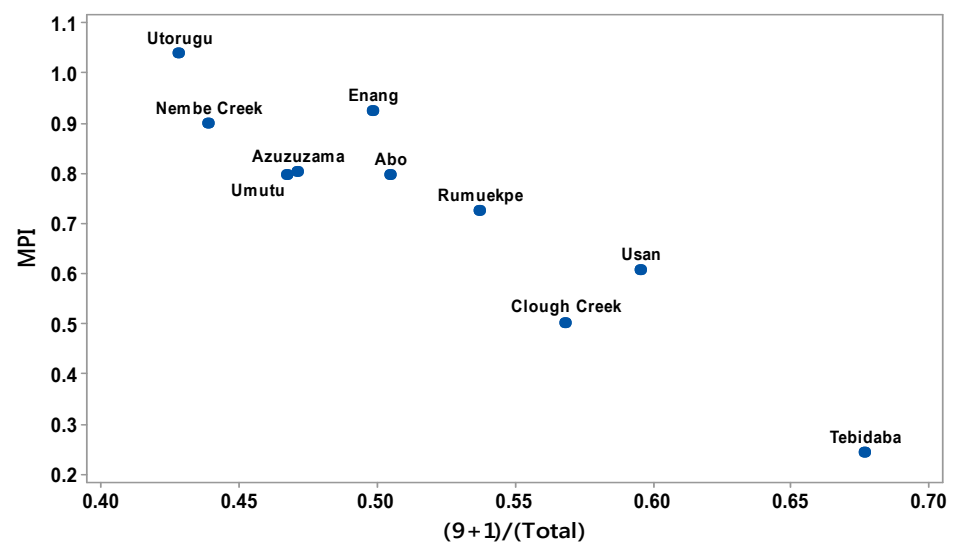

Figure 5: The plot of $(9+1) \mathrm{MP} /($ Total MP) and $(9+1) \mathrm{MP} /(3+2) \mathrm{MP}$.

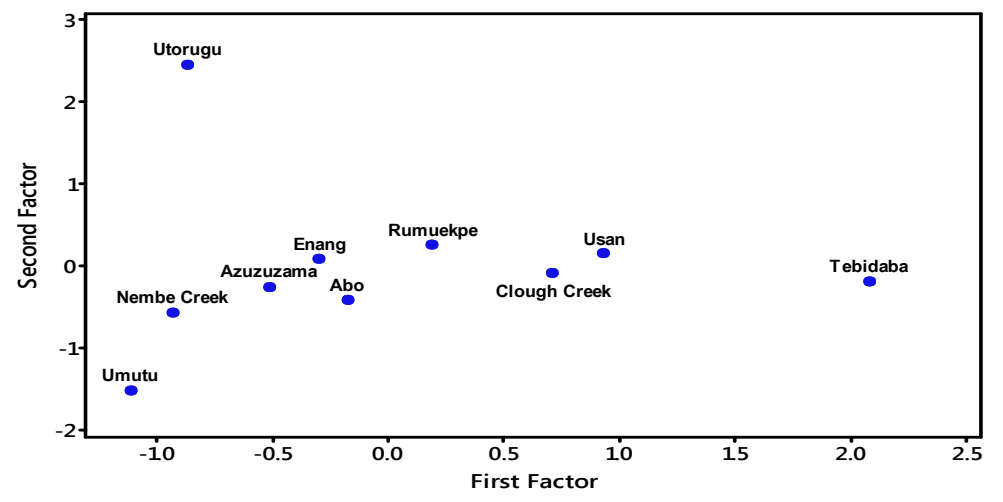

Figure 6: The score plot of PCA analysis. 


\section{Petroleum \& Petrochemical Engineering Journal}

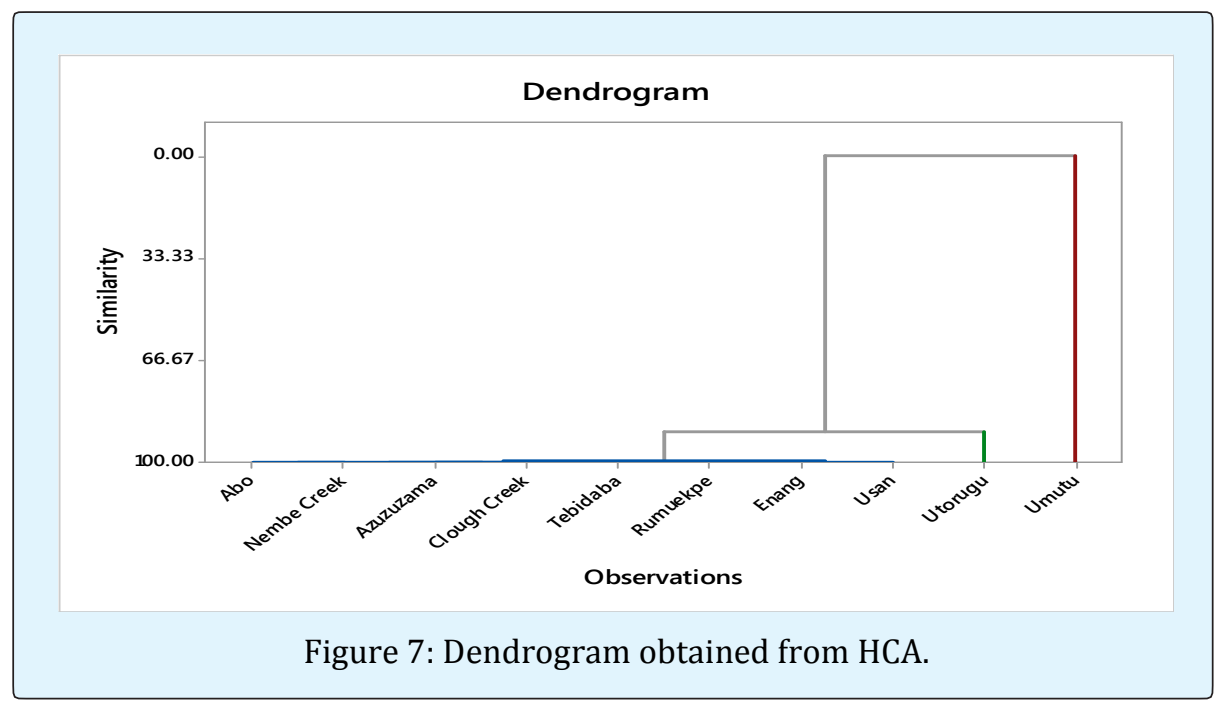

\section{Other Correlations}

The relationship between $(9+1) \mathrm{MP} /($ Total MP) and $(9+1) \mathrm{MP} /(3+2) \mathrm{MP}$ were observed to be a linear relationship with a correlation coefficient of 0.968 , which implies about $96.8 \%$ of similarity between the two parameters in the plot. This invariably implies that $(9+1) \mathrm{MP} /(3+2) \mathrm{MP}$ could be used to infer maturity statues.

A robust multivariate analysis was carried out for the parametric ratio used in this study. The PCA (principal component analysis) was done for two factors, the first explain about $44 \%$ of the difference, while the second factor explains $26 \%$ of the variations. The two factors explain $70 \%$ of the variations. The score plot (Figure 6) obtained from the principal component analysis show that Umutu and Utorugu oils are significantly discriminated from the other oils. The HCA (hierarchical cluster analysis) as shown by the dendrogram in Figure 8, infers Umutu oil is very dissimilar with other oils, however Utorugu oil is similar to other oils by $89.84 \%$ while the rest are similar to each other by $99.44 \%$. The HCA was performed on conditions of linkage method as complete and distance measured as Square Euclidean distance.

\section{Conclusions}

The study was carried on Niger delta oils and for the purpose of identifying phenanthrene and methylphenanthrene in Niger Delta oils. GC-MS is the analytical method of choice, $\mathrm{m} / \mathrm{z}=178$ and 192 chromatograms were extracted for phenanthrene and methylphenanthrene from the result data file using an Enhanced MSD ChemStation 2011 software by Agilent Technologies. Abundance for each compound was obtained from the percent report and the parametric ratios were calculated. The DBT/P and $\mathrm{Pr} / \mathrm{Ph}$ plot showed that most of the oils were generated by organic matter deposited in fluvial-deltaic environment except the Umutu oil. MPI values used for evaluating the maturity of the oils showed that the maturity varies from early mature to late mature. The PCA score plot show that the Umutu and Utorugu oils are discriminated from others. But the HCA dendrogram show that Umutu oil significantly different from other oils by quantitative compositional variations not by classical genetic classification.

\section{References}

1. Stogiannidis E, Laane R (2015) Source Characterization of Polycyclic Aromatic Hydrocarbons by Using Their Molecular Indices: An Overview of Possibilities. In: Whitacre DM (Ed.), Reviews of Environmental Contamination and Toxicology. Springer International Publishing, Switzerland, 234: 50-108.

2. Kvalheim OM, Christy AA, Telnes N, Bjorseth A (1987) Maturity determination of organic matter in coals using the methylphenanthrene distribution. Geochimica et Cosmochimica Acta 51(7): 1883-1888.

3. Zakir Hossain HM, Sampei Y, Roser BP (2009) Influence of organic matter type on the distribution of tri-aromatic hydrocarbons in Tertiary mudstones in 


\section{Petroleum \& Petrochemical Engineering Journal}

the Sylhet Basin, Bangladesh. Res Org Geochem 25: 39-52.

4. BudzinskiH, Garrigues P, Bernard G, Bellocq J, Hinrichs K, et al. (1997) Identification Of Polycyclic Aromatic Hydrocarbons In Sediments From The Amazon Fan: Occurrence and Diagenetic Evolution. In: Flood R, Piper D, Klaus A, Peterson L (Eds.), Proceedings of the Ocean Drilling Program, Scientific Results, pp: 555-564.

5. Dim CIP (2017) Hydrocarbon Prospectivity in the Eastern Coastal Swamp Depo-belt of the Niger Delta Basin. ${ }^{\text {st }}(E d n$.), Springer International Publishing, pp: 71.

6. Reijers TJ (2011) Stratigraphy and sedimentology of the Niger Delta. Geologos 17(3): 133-162.

7. Peters KE, Walters CC, Moldowan JM (2005) The Biomarker Guide: Biomarkers and Isotopes in Petroleum System sand Earth History. $2^{\text {nd }}(E d n$.$) ,$ Cambridge University Press, Cambridge.

8. Stout SA, Wang Z (2016) Standard Handbook Oil Spill Environmental Forensics; Fingerprinting and Source Identification. $2^{\text {nd }}$ (Edn.), Elsevier, pp: 1142.

9. Hunt MJ (1996) Petroleum Geochemistry and Geology. 2nd (Edn.), New York: W.H freman and Company.
10. Hanson AD, Moldowan JM, Liang DG, Zhang SC (2000) Molecular Organic Geochemistry of the Tarim Basin Northwest China. The American Association of Petroleum Geologists Bulletin 84(8): 1109-1128.

11. Tyson R (1995) Sedimentary Organic Matter; Organic facies and palynofacies. $1^{\text {st }}$ (Edn.), Springer Netherlands, pp: 615.

12. Hughes WB, Holba AG, Dzou LIP (1995) The ratios of dibenzothiophene to phenanthrene and pristane to phytane as indicators of depositional environment and lithology of petroleum source rocks. Geochimica et Cosmochimica Acta 59(17): 3581-3598.

13. Pepper AS, Corvit PJ (1995) Simple kinetic models of petroleum formation Part I: oil and gas generation from kerogen. Marine and Petroleum Geology 12(3): 291-319.

14. Volk H, George S, Kempton R, Liu K, Ahm M (2007) Petroleum migration in the Georgina Basin: Evidence from the geochemistry of oil inclusions and bitumens. Proceedings of the Central Australian Basins Symposium (CABS), Alice Springs, Northern Territory, Northern Territory Geological Survey, Special Publication 2(2): 282-303. 